\title{
Discrepancy in T Cell Clonal Expansions in Synovial Fluid and Peripheral Blood from Rheumatoid Arthritis Patients
}

\author{
In Hong Choi', Youngjoon Chwae', Soo Kon Lee ${ }^{2}$ \\ Minkyung Chu', Joo Deuk Kima and Se Jong Kim ${ }^{1}$
}

\begin{abstract}
Rheumatoid arthritis ( $R A$ ) is an autoimmune cinsease involving the synovial membrane of peripheral joints. $T$ cells specific for self antigens may play a wivical role. Identification of $T$ cell receptors (TCR) of such specific $T$ cell clones is very important for treatment, prevention and identification of relevant autoantigens. To identify specific $T$ cells, TCR VB family repertoire and the clonal expansion of $T$ cells were analyzed in this siudy. The percentage of $V \beta 5^{+}$or $V \beta 8^{+}$cells in the synovial fluid mononuclear cells (SFMCs) was similar to that in the peripheral blood mononuclear cells (PBMCs). However, the percentage of $D R^{+} T$ cells in the SFMCs was higher $(p<0.01)$. Analyzing the clonality of $T$ cells in $8 V \beta$ families (VB1, V35,VB8,VB14,VB16,VB17,VB18,VB20), clonal expansions in $C D 8^{+} T$ cells from the SFMCs inore found more frequently than in the PBMCs. The patterns of clonal expansions were discrepant between the SFMCs and the PBMCs even in the same patient, which suggests several inflamed tissue specific $T$ cell clonal expansions in the SFMCs. These $T$ cell clones might be activated by autoantigens which are not identified yet and responsible for the RA pathogenesis.
\end{abstract}

Key Words: Rheumatoid arthritis, synovial fluid $T$ cells, $T$ cell receptor, CDR3, clonal expansions, $\mathrm{DR}^{+} \mathrm{T}$ cells

Rheumatoid arthritis (RA) is an autoimmune disease characterized by a chronic inflammatory process, primarily involving the synovial membrane of peripheral joints (Harris 1990). The majority of RA patients carries HLA-DR1, HLA-DR4 or both antigens in Caucasians (Stastny 1978, Nepom et al. 1989), but other genetic components are also clearly in-

\section{Received January 13, 1995}

Accepted March 7, 1995

Department of Microbiology, Yonsei University College of Medicine, Seoul, Korea

This paper was supported by Non Directed Research Fund, Korea Reserach Foundgtion, 1993.

Address request for reprints to Dr. In Hong Choi, Department of Microbiology, ${ }^{2}$ Department of Internal Medicine, Yonsei University College of Medicine, C.P.O. Box 8044, Seoul 120-752, Korea volved in the susceptibility to the disease. Some evidences suggest that $T$ cells specific for self antigens may play a critical role in the initiation of RA. Activated $T$ cells are found in the inflamed synovium (van Boxel and Paget 1975, Howel et al. 1991, Bucht et al. 1992, Cooper et al. 1994) and treatment with immunosuppressive drugs, like cyclosporine, shows clinical efficacy (Shirosky et al. 1989).

Cultivated $T$ cells from RA synovial tissues often display dominant $T$ cell receptors (TCR), V $\beta 14,16$, and 17, which are characteristic of clonal $\mathrm{T}$ cell expansion (Chatila et al. 1990). These findings are indicative of in situ activation of specific $T$ cell populations by synovial antigens and are supportive of the role for these $T$ cells in the pathogenesis of RA. Analysis of animal models of autoimmune 
diseases has provided some evidence for TCR oligoclonality. Oligoclonal TCR repertoire is involved in the induction and maintenance of experimental allergic encephalomyelitis in rats (Urban et al. 1988) and antibodies directed against the expressed $\beta$ chain variable regions $(\mathrm{V} \beta), \mathrm{V} \beta 8.2$, can be used to prevent and treat the disease in B 10 PL mice (Zaller et al. 1990). Identification of TCR V $\beta$ family of such specific $T$ cell clone is very important, because those TCR may provide a highly selective target for treatment as well as vaccine and may be used to identify relevant autoantigens.

In this study we used a simple PCR assay to study the clonality of $T$ cells. The CDR3 region of the TCR $\beta$ chain is formed by the joining of V, D and J gene segments (Candeias et al. 1991) (Fig. 1), accompanied by the random addition of $N$ or $P$ nucleotides.

Thus this CDR3 of the TCR $\beta$ chain varies in length as well as in sequences. This length variation forms the basis of the CDR3 length assay.

To investigate the oligoclonality of $T$ cells in $R A, T C R V \beta$ family repertoire for $V \beta 5$ and $V \beta 8$ were analyzed by flow cytometry and the clonal expansions of single gene families ( $V \beta 1$, $\mathrm{V} \beta 14, \mathrm{~V} \beta 16, \mathrm{~V} \beta 17, \mathrm{~V} \beta 18, \mathrm{~V} \beta 20$ ) were analyzed by two step PCR in $T$ cells from peripheral blood or synovial fluid of RA patients.

\section{MATERIALS AND METHODS}

\section{RA patients}

Synovial fluid and peripheral blood were collected from $12 \mathrm{RA}$ patients at the same time. Ten patients were female and 2 patients were male. Disease duration varies from 6 months to 3 years.

\section{Separation of $\mathrm{CD4}^{+}$or $\mathrm{CD8}^{+} \mathrm{T}$ cells}

Synovial fluid mononuclear cells (SFMCs) or peripheral blood mononuclear cells (PBMCs) were obtained by Ficoll-Hypaque (Lymphoprep, Nyegaard, Oslo, Norway) density gradient centrifugation. The cells were washed three times in RPMI 1640 and resuspended in RPMI $1640-10 \%$ fetal calf serum at the con- centration of $2 \sim 3 \times 10^{6}$ cells $/ \mathrm{ml}$. Positive selection for $\mathrm{CD}^{+}$cells was carried out by incubating mononuclear cells with anti-CD8 immunomagnetic beads (Dynal, Great Neck, $\mathrm{NY}$ ) for $30 \mathrm{~min}$ at $4^{\circ} \mathrm{C}$ on a rotating shaker. The unbound cells were then incubated with anti-CD4 immunomagnetic beads (Dynal, Great Neck, NY) for the selection of $\mathrm{CD}^{+} \mathrm{T}$ cells.

\section{Surface marker study}

Fluorescein isothiocyanate (FITC) or phycoerythrin conjugated monoclonal antibodies of anti-CD19, anti-CD45, anti-CD4, anti-CD8 or anti-DR (Becton Dickson, San Jose, CA) were used. For TCR $\beta$ chain, FITC conjugated antiVB5 or anti-VB8 monoclonal antibodies (T Cell Scientific, Cambridge, MA) were used. Cells (0. $5 \sim 1 \times 10^{6}$ cells $/ \mathrm{ml}$ ) in PBS- $0.1 \%$ bovine serum albumin (BSA) were incubated for $30 \mathrm{~min}$ at $4^{\circ} \mathrm{C}$ and washed once with PBS- $0.1 \%$ BSA. Propidium iodide (Sigma, St. Louis, MO) at final concentration of $25 \mathrm{\mu g} / \mathrm{ml}$ was used to discriminate dead cells from live cells. A total of 10,000 to 20,000 cells were analyzed by FACStar II (Becton Dickson, San Jose, CA).

\section{Analysis of CDR3 size}

Total RNA was isolated by acid guanidium isothiocyanate-phenol-chloroform extraction (Chomczynski and Sacchi, 1987). Total RNA (1 $\sim 5 \mu \mathrm{g}$ ) was used for the first strand cDNA synthesis using random hexamer $\left(: \operatorname{pd}(\mathrm{N})_{k}\right.$, Pharmacia, Oslo, Sweden) 2 O.D. units. The cDNA synthesis was performed with $600 \mathrm{U}$ of MLV reverse transcriptase (Gibco BRL, Gaithersburg, MD) at $42^{\circ} \mathrm{C}$ for 1 hour in a total volume of $100 \mu \mathrm{l}$.

The CDR3 length analysis was carried out using a two step PCR. V $\beta$ family specific sense primer combined with a antisense primer specific for the $C$ region $(C \beta)$ was used in the first round amplification (Table 1). A total of $8 \sim 10 \mu \mathrm{l}$ of the cDNA was used for the amplification of each $V \beta$ family. The conditions for the PCR on the cycle sequencer (PerkinElmer Corp., Norwalk, CT, model 2600) was as follows : denaturation at $94^{\circ} \mathrm{C}$ for $1 \mathrm{~min}$, annealing at $55^{\circ} \mathrm{C}$ for $1 \mathrm{~min}$ and extension at $72^{\circ} \mathrm{C}$ for $1 \mathrm{~min}$. PCR buffer condition was 10 $\mathrm{mM}$ Tris- $\mathrm{HCl}$ (pH8.3), $2.0 \mathrm{mM} \mathrm{MgCl}_{2}, 50 \mathrm{mM}$ 
Table 1. Sequences of primers for the first PCR

\begin{tabular}{l}
\hline Primers $5^{\prime}$ - $3^{\prime}$ \\
\hline V $\beta 1$ GCA CAA CAG TTC CCT GAC TTG CAC \\
V $\beta 5$ ATA CTT CAG TGA GAC ACA GAG AAA C \\
V $\beta 8$ ATT TAC TTT AAC AAC AAC GTT CCG \\
V $\beta 14$ GTC TCT CGA AAA GAG AAG AGG AAT T \\
V $\beta 16$ AAG AGT CTA AAC AGG A GA GTC C \\
V $\beta 17$ CAG ATA GTA AAT GAC TTT CAG \\
V $\beta 18$ GAT GAG TCA GGA ATG CCA AAG GAA \\
V $\beta 20$ AGC TCT GAG GTG CCC AGA ATC TC \\
C TTC TGA TGG CTC AAA CAC
\end{tabular}

Table 2. Sequences of primers for the second PCR

\begin{tabular}{cl}
\hline \hline Primers & $5^{\prime}$ \\
\hline V $\beta 1$ & C TCA GCT TTG TAT TTC TGT G \\
V $\beta 5$ & T CGG CCC TTT ATC TTT GCG C \\
V $\beta 8$ & C TCA GCT GTG TAC TTC TGT G \\
V $\beta 14$ & G ACC TCT CTG TAG TTC TGT G \\
V $\beta 16$ & T TCT GGA GTT TAT TTC TGT G \\
V $\beta 17$ & G ACA GCT TTC TAT CTC TGT G \\
V $\beta 18$ & T TCG GCA G(GorC) T TAT TTC TGT G \\
V $\beta 20$ & C TCT GGC TTC TAT CTC TGT G \\
\hline
\end{tabular}

$\mathrm{KCl}$, with 20 pmol of each primer in $50 \mu \mathrm{l}$ reaction volume with $2.5 \mathrm{U}$ of $T a q$ polymerase (Korea Biotec. Co., Taejon, Korea). After 35 cycles, an additional extension at $72^{\circ} \mathrm{C}$ for 10 min was carried out. The PCR products were visualized on $1 \%$ agarose gel and $1 \sim 3 \mu$ l of these products served as the template for the next round of PCR.

The sense primers that were nested $3^{\prime}$ to the $\mathrm{V} \beta$ specific primer (V $\beta-\mathrm{N})$ (Table 2) and the antisense primer, $C \beta$ were used in the second round of PCR. For the second amplification, the $\mathrm{C} \beta$ primer was end labeled with $\gamma_{-}{ }^{32} \mathrm{P}$ ATP using T4 kinase (Gibco BRL, Gaithersburg, MD). PCR condition were identical to those of first round PCR, except that primer concentration was reduced to $3 \mathrm{pmol}$ per $50 \mu \mathrm{l}$ reaction volume. After 15 cycles, each $3 \sim 5 \mu l$ of the radioactive $P C R$ product was loaded on $6 \%$ poly acrylamide sequencing gel. Bands were visualized after overnight exposure to Kodak

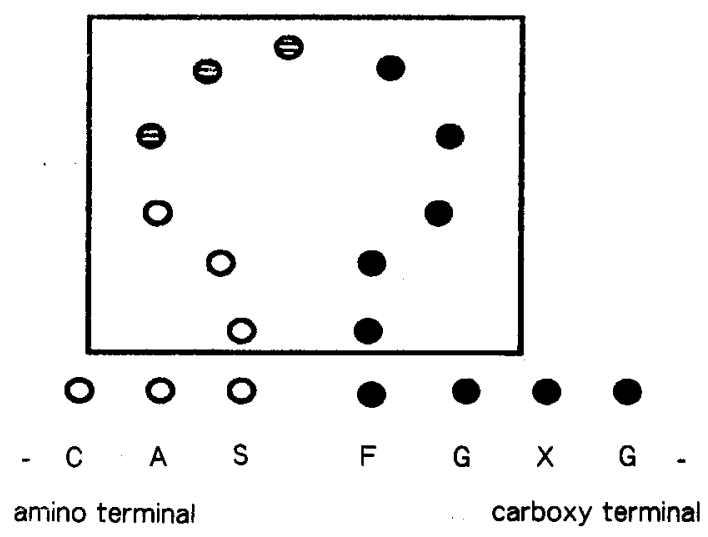

O amino acids encoded by $\vee$ gene

$\theta$ amino acids encoded by $D$ gene

amino acids encoded by $J$ gene

Fig. 1. Schematic organization of CDR3 in TCR VB chain. CDR3 loop is expressed as a box. Junctional diversity can be occurred between $V$ and $D$ or $D$ and Jjoining sites.

AR film.

Usually CDR3 is defined as a region from the consensus amino acid sequence of CASS (C; cysteine, A; alanine, S; serine) at the $3^{\prime}$ end of most $V \beta$ segment to the $J$ region encoded FGXG (F; phenylalanine, G; glycine, X; any amino acid). In this study CDR3 length was defined as the distance from the second $\mathrm{S}$ in $\mathrm{V}$ region to any amino acid before FGXG in the $\mathrm{J}$ region (Fig. 1). Thus, the CDR3 included in the sequence V $\beta$-CASSLNWSQDTQFGPG$\mathrm{J} \beta$ would count as nine amino acids.

\section{Statistics}

Statistical analysis employed the MannWitney test or Wilcoxon Signed Rank test.

\section{RESULTS}

Expression of CD3, CD19, CD4, CD8 and DR molecules in the SFMCs or PBMCs

$\mathrm{CD}^{+}, \mathrm{CD}^{+}{ }^{+}, \mathrm{CD}^{+}$and $\mathrm{CD}^{+}$cells among the PBMCs or SFMCs were analyzed by mono-clonal antibodies. The mean percentage 
Table 3. Percentages of $\mathrm{CD}^{+}$and $\mathrm{CD}^{+} 9^{+}$cells in rheumatoid arthritis

\begin{tabular}{|c|c|c|}
\hline group Phenotype & $\begin{array}{c}\mathrm{CD}^{+} \text {cells } \\
(\mathrm{n}=12)\end{array}$ & $\begin{array}{c}\mathrm{CD}^{\mathrm{C}} 9^{+} \text {cells } \\
(\mathrm{n}=12)\end{array}$ \\
\hline $\begin{array}{l}\text { synovial fluid } \\
\text { mononuclear cells } \\
\text { peripheral blood }\end{array}$ & $75.1 \pm 11.9^{*}$ & $1.6 \pm 1.8^{* *}$ \\
\hline mononuclear cells & $65.5 \pm 20.6$ & $9.4 \pm 7.2$ \\
\hline
\end{tabular}

Mononuclear cells were stained with anti-CD3 or anti-CD19 monoclonal antibodies and total $10,000 \sim$ 20,000 cells were analyzed. Values are mean \pm S.D. ${ }^{*} p$ $>0.01 .{ }^{* *} p=0.007$.

Table 4. Percentages of $\mathrm{CD}^{+}$and $\mathrm{CD8}^{+} \mathrm{T}$ cells in rheumatoid arthritis

\begin{tabular}{ccc}
\hline \hline Proup & $\begin{array}{c}\text { Phenotype } \\
(\mathrm{n}=12)\end{array}$ & $\begin{array}{c}\mathrm{CD}^{+} \mathrm{T} \text { cells } \\
(\mathrm{n}=12)\end{array}$ \\
\hline $\begin{array}{c}\text { synovial fluid } \\
\text { mononuclear cells }\end{array}$ & $43.3 \pm 17.7^{*}$ & $30.3 \pm 15.5^{*}$ \\
$\begin{array}{c}\text { peripheral blood } \\
\text { mononuclear cells }\end{array}$ & $45.2 \pm 16.2$ & $19.9 \pm 11.9$ \\
\hline
\end{tabular}

Mononuclear cells were stained with anti-CD4 or anti-CD8 monoclonal antibodies and total $10,000 \sim$ 20,000 cells were analyzed. Values are mean \pm S.D. ${ }^{*} p$ $>0.01$.

$(75.1 \pm 1.9 \%)$ of $\mathrm{CD3}^{+}$cells in the SFMCs was higher than that $(65.5 \pm 20.6 \%)$ of the PBMCs and the mean percentage $(1.6 \pm 1.8 \%)$ of $\mathrm{CD} 19^{+}$ cells in the SFMCs was lower than that $(9.4 \pm$ $7.2 \%$ ) of the PBMCs (Table 3). But only the difference in $\mathrm{CD}^{+} 9^{+}$cells was significant (Table 3, $p=0.007)$. The mean percentage $(30.3$ $\pm 15.5 \%$ ) of $\mathrm{CD}^{+}$cells in the SFMCs was higher than that $(19.9 \pm 11.9 \%)$ of the PBMCs but there was no significance (Table $4, p>0.1$ ).

To know the proportion of activated $\mathrm{T}$ cells, $\mathrm{DR}^{+} \mathrm{T}$ cells were evaluated. The mean percentage $(32.7 \pm 15.2 \%)$ of $\mathrm{DR}^{+} \mathrm{T}$ cells in the SFMCs was significantly higher than that $(2.2$ $\pm 1.0 \%$ ) of the PBMCs (Fig. 2, $p<0.01$ ).
Table 5. Percentages of $\mathrm{V} \beta 5^{+}$and $\mathrm{V} \beta 8^{+}$cells in rheumatoid arthritis

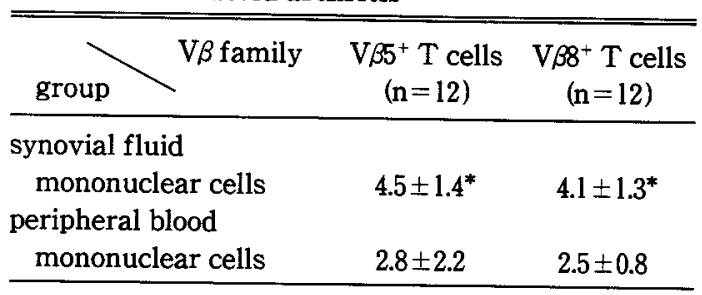

Mononuclear cells were stained with anti-V $\beta 8$ monoclonal antibodies and total $10,000 \sim 20,000$ cells were analyzed. Values are mean \pm S.D. ${ }^{*} p>0.01$.

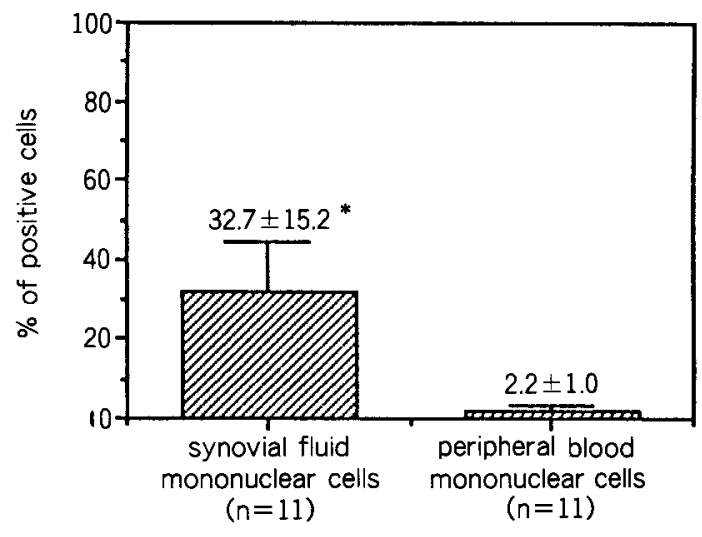

Fig. 2. DR expression in rheumatoid arthritis patients. Mononuclear cells were stained with anti-DR or anti-CD3 monoclonal antibodies and total 10,000 20,000 cells were analyzed. Values are mean $\pm S . D^{*} p<0.01$.

Comparison of the $\mathrm{V} \beta$ gene usage of the SFMCs and PBMCs

To analyze TCR $\mathrm{V} \beta$ repertoire, $\mathrm{V} \beta 5^{+}$or $\mathrm{V} \beta 8^{+}$ cells were evaluated (Table 5) by monoclonal antibodies. The mean percentage of $\mathrm{V} \beta 5^{+}$cells $(4.5 \pm 1.4 \%)$ and $V \beta 8^{+}$cells $(4.1 \pm 1.3 \%)$ in the SFMCs were higher than that of the PBMCs ( $2.8 \pm 2.2 \%$ and $2.5 \pm 0.8 \%$, respectively). But the differences were not significant (Table 5, $p>0.1$ ). 
In Hong Choi, et al.

< PBMC >

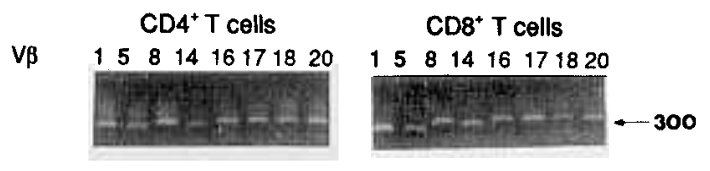

$\langle$ SFMC >

$\mathrm{CD}^{+} \mathrm{T}$ cells

V $\beta$

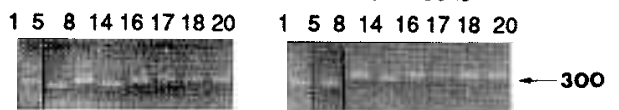

Fig. 3. First PCR products (patient \#1). Ten $\mu$ l of each PCR products were analyzed on $1.5 \%$ agarose. The size marker $(\leftarrow 300)$ indicates 300 bp. $P B M C=$ peripheral blood mononuclear cells. $S F M C=$ synovial fluid mononuclear cells.
Comparison of the clonality of the SFMCs and PBMCs

Among 3 RA patient, the clonal expansions were evaluated by two step PCR. All the $8 \mathrm{~V} \beta$ genes tested in this study were detected in both the SFMCs and PBMCs samples (Fig. 3).

Among $\mathrm{CD}^{+} \mathrm{T}$ cells in the SFMCs of $3 \mathrm{RA}$ patients, 5 clonal expansions were detected (Fig. 4 \& Fig. 5). In the SFMCs from patient \#1, there was one clonal expansion in $V \beta 18^{+}$ $T$ cells (CDR3 length: 8 amino acids). In the SFMCs from patient $\# 2$, there were 3 clonal expansions; 2 in $V \beta 5^{+} \mathrm{T}$ cells (CDR3 length: 8 and 10 amino acids) and one in $\mathrm{V} \beta 14^{+} \mathrm{T}$ cells
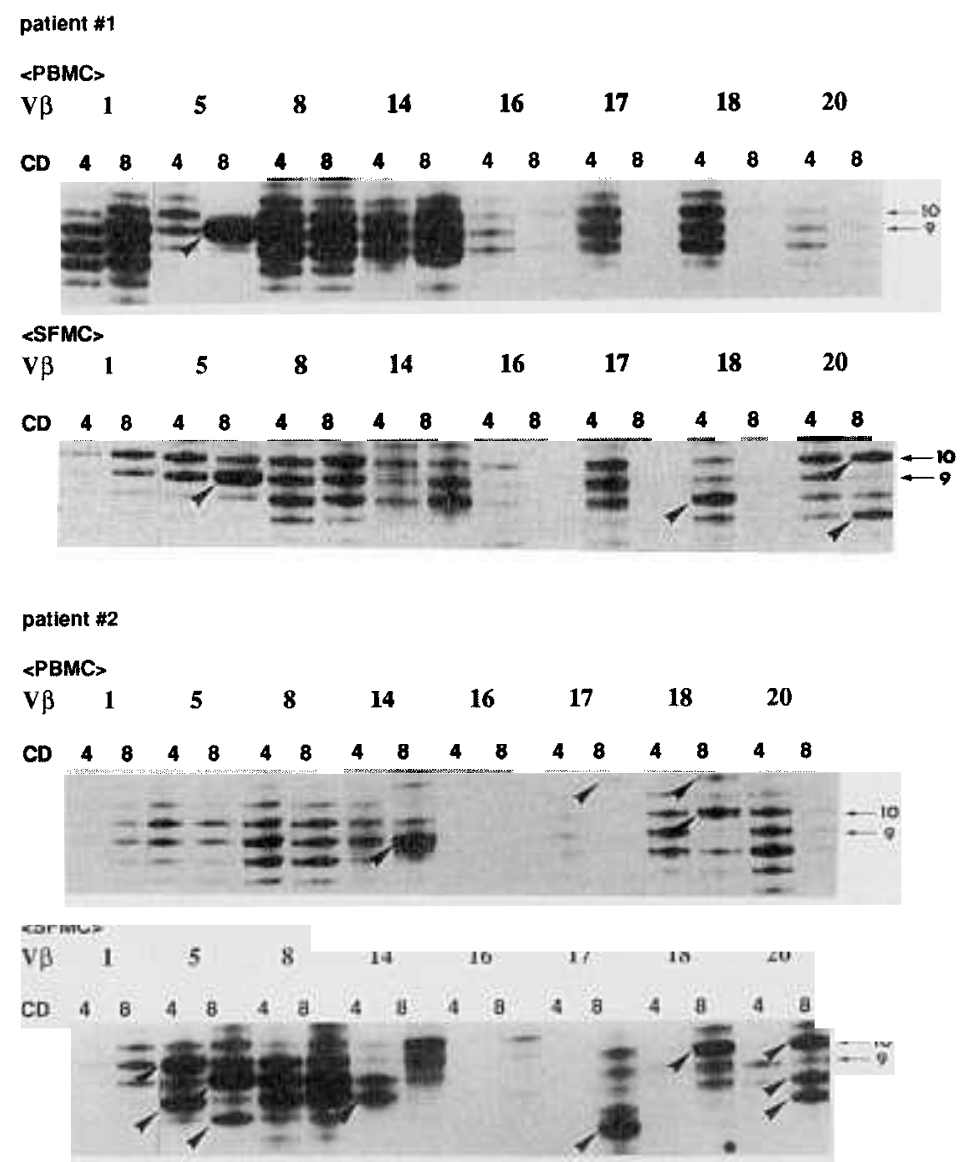

Fig.4. Oligoclonal expansions in $T$ cells of patient \#1 and patient \#2. The CDR3 length profile was analyzed by two step PCR. Each 3 5 $\mu$ ll of radiolabelled second PCR products were separated on $6 \%$ denaturing poly. acrylamide gel. Bands were visualized after overnight exposure. The size marker (-9) indicates a CDR3 with 9 amino acids and the other size marker $(\leftarrow 10)$ indicates $a$ CDR3 with 10 amino acids. 


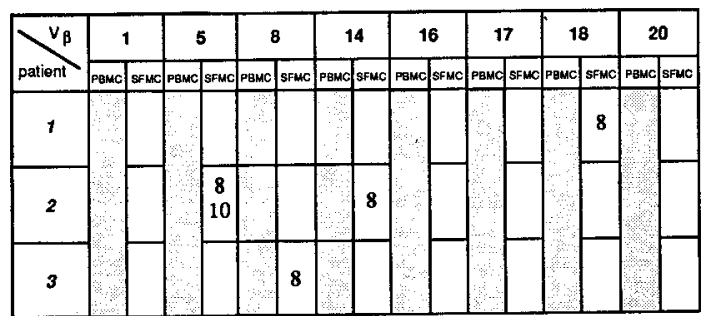

Fig. 5. Oligoclonal expansions in $C D 4^{+} T$ cells from peripheral blood or synovial fluid among rheumatoid arthritis patients. CDR3 length profile was analyzed by two sep PCR. The value is the amino acid number of CDR3 which shows the dominant clone. $P B M C=$ peripheral blood mononuclear cells. SFMC=synovial fluid mononuclear cells. $\square / \square=$ No dominant band was shown.

(CDR3 length: 8 amino acids). In the SFMCs from patient \#3, there was one clonal expansion in $\mathrm{V} 8^{+} \mathrm{T}$ cells (CDR3 length: 8 amino acids). There was no clonal expansion of $\mathrm{CD4}^{+}$ $T$ cells from the PBMCs of 3 RA patients (Fig. 4 \& Fig. 5).

Among $\mathrm{CD} 8^{+} \mathrm{T}$ cells from the SFMCs of 3 RA patients, a total of 10 clonal expansions were detected (Fig. 4 \& Fig. 6). In the SFMCs from patient $\# 1$, there were 3 clonal expansions; one in $\mathrm{V} \beta 5^{+} \mathrm{T}$ cells (CDR3 length: 9 amino acids) and 2 in $\mathrm{V} \beta 20^{+} \mathrm{T}$ cells (CDR3 length: 7 and 10 amino acids). In the SFMCs from patient \#2, there were 7 clonal expansions; two in $\mathrm{V} \beta 5^{+} \mathrm{T}$ cells (CDR3 length: 7 and 9 amino acids), one in $\mathrm{V} \beta 17^{+} \mathrm{T}$ cells (CDR3 length: 6 amino acids), one in $\mathrm{V} \beta 18^{+} \mathrm{T}$ cells (CDR3 length: 10 amino acids) and 3 in $\mathrm{V} \beta 20^{+} \mathrm{T}$ cells (CDR3 length: 7, 8 and 10 amino acids). In the SFMCs from patient \#3, there was no clonal expansion.

In contrast to the 10 clonal expansions of $\mathrm{CD}^{+}$SFMCs, a total of 7 clonal expansions were detected among $\mathrm{CD} 8^{+} \mathrm{T}$ cells from the PBMCs of 3 RA patients (Fig. 4 \& Fig. 6). In the PBMCs from patient $\# 1$, there was one clonal expansion in $\mathrm{V} 5^{+} \mathrm{T}$ cells (CDR3 length: 9 amino acids). In the PBMCs from patient $\# 2$, there were 4 clonal expansions; one in $\mathrm{V} \beta 14^{+} \mathrm{T}$ cells (CDR3 length: 9 amino

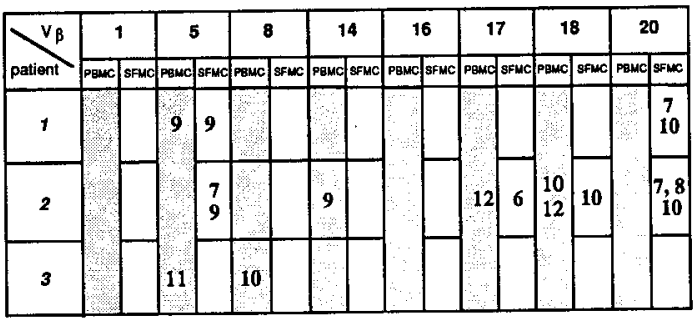

Fig. 6. Oligoclonal expansions in $C D 8^{+} T$ cells from peripheral blood or synovial fluid among rheumatoid arthritis patients. CDR3 length profile was analyzed by two step PCR. The value is the amino acid number of $C D R 3$ which shows the dominant clone. $P B M C=$ peripheral blood mononuclear cells. $S F M C=$ synovial fluid mononuclear cells. $\square / \square=$ No dominant band was shown.

acids), one in $\mathrm{V} \beta 17^{+} \mathrm{T}$ cells (CDR3 length: 12 amino acids), and 2 in $\mathrm{V} \beta 18^{+} \mathrm{T}$ cells (CDR3 length: 10 and 12 amino acids). In the PBMCs from patient \#3, there were 2 clonal expansions; one in $\mathrm{V} \beta 5^{+} \mathrm{T}$ cells (CDR3 length: 11 amino acids) and one in $\mathrm{V} \beta 8^{+} \mathrm{T}$ cells (CDR3 length: 10 amino acids).

\section{DISCUSSION}

In this study specific clonal expansions of $\mathrm{CD}^{+} \mathrm{T}$ cells in the synovial fluid from RA patients were analyzed. Our study demonstrates consistent $T$ cell clonal expansions in the SFMCs. Previous reports of repeated TCR $\mathrm{V} \beta 14^{+}$and $\mathrm{V} \beta 17^{+} \mathrm{T}$ cell expansions in synovial fluid or tissue have suggested that clonal $T$ cell expansions might be an important aspects of RA pathogenesis (Howel et al. 1991; Paliard et al. 1991, Scottini et al. 1992).

There are several critical variables to be considered when comparing studies on the analysis of TCR repertoire. The source of the cells, where they are obtained from synovial fluid or synovial tissue and whether they are obtained from relatively intact joints or from end-stage joints could influence the results. Another variable is whether the cells have or 
have not expanded in vitro as well as the stimulation protocol that was used. In this study, we collected synovial fluid samples from patients with actively inflamed, but not end-stage, joint. The oligoclonal expansion of $T$ cells were analyzed directly from the aspirated SFMCs and compared with the PBMCs from the same individual without in vitro expansions.

There are two possibilities that could account for a relative increase in mRNA amount with specific CDR3. One possibility is an absolute increase in the number of cells expressing specific CDR3 and the other possibility is the disproportional increase of mRNA expression on a $\mathrm{T}$ cell because they are selectively activated in vivo. In addition it is possible that RNA levels may not correlate well with the cell surface receptor expression. But no distortion was detected between the RNA and protein levels (Singer et al. 1990). Further, it is unlikely that the degree of $T$ cell activation results in substantial distortion of TCR expression (Paliard et al. 1990), although the possibility of the up-regulation of mRNA could not be ruled out completely.

Analyzing $\mathrm{T}$ cell clonality we attemped to speculate on what type of antigen(s) may be involved. Generally, $T$ cell expansions might be induced by a superantigen or a conventional antigen. Superantigens bind to major histocompatibility complex class II molecules of antigen presenting cells and to certain $\mathrm{V} \beta$ chains of TCR, irrespective of the antigen binding specificity of TCR. The initial hyperactivation by a superantigen results in the release of several lymphokines (Meithke et al. 1993) and the expression of functional IL-2 receptor (Meithke et al. 1994). However it caused the down-regulation of TCR complex of the responding $\mathrm{V} \beta^{+} \mathrm{T}$ cells after $6 \sim 20$ hours of stimulation (Heeg et al. 1993). Superantigens activate $\mathrm{T}$ cells by a V $\beta$ family specific pattern (Choi et al. 1991), while conventional antigens activate $T$ cells by a clonotype specific pattern. Therefore, in order to discriminate family specific expansions and clonotype specific expansions of $T$ cells from RA patients, the analysis of CDR3 size was performed in this study.
First, we attemped to find out the evidence of $T$ cell activation in the synovial site. As a result, we found there were definite $T$ cell activations. The percentage of $\mathrm{DR}^{+} \mathrm{T}$ cells in the SFMCs was increased significantly in comparison to that in the PBMCs.

The TCR V $\beta$ family repertoire was analyzed by a serological method (Posnett et al. 1988). Until now serological method for $V \beta$ repertoire had some serious limitations because only a few monoclonal antibodies specific for certain human $\mathrm{V} \beta$ regions were available. $\mathrm{T}$ cells bearing $V \beta 5$ or $V \beta B$ were evaluated because $\mathrm{V} \beta 5^{+}$or $\mathrm{V} \beta 8^{+} \mathrm{T}$ cells are known to be activated by the superantigenic stimulation of staphylococcal exotoxins. We found the percentage of $T$ cells bearing $V \beta 5$ or $V \beta 8$ was not increased in the SFMCs, which suggests no expansions of $T$ cells bearing $V \beta 5$ or $V \beta 8$.

To find out whether the specific $V \beta^{+} T$ cells in the SFMCs were oligoclonal, a two step PCR was done. In this study, single gene families $(V \beta 1, V \beta 14, V \beta 17, V \beta 18, V \beta 20)$ and $V \beta 5$ $\mathrm{V} \beta 8$ were analyzed. First of all, all the $8 \mathrm{~V} \beta$ genes were used in the SFMCs or PBMCs. Although the majority of $T$ cells within the RA joint were polyclonal, the $T$ cells important in the pathogenesis of RA are likely to undergo in vivo expansions or activation with exogenous IL-2 because they might have IL-2 receptor. In the SFMCs, clonal expansions in $\mathrm{CD8}^{+} \mathrm{T}$ cells were found in all three RA patients tested. There were also clonal expansions in the PBMCs from the same 3 RA patients. However, the patterns of clonal expansions were diverse. $\mathrm{V} \beta 14^{+}$or $\mathrm{V} \beta 17^{+} \mathrm{T}$ cells increased and were related to superantigen in RA (Paliard et al. 1991). But in our study, the evidence for involvement of superantigen activating $\mathrm{V} \beta 14^{+}$or $\mathrm{V} \beta 17^{+} \mathrm{T}$ cells was not found. The clonal expansion detected in $V \beta 14^{+}$ $\mathrm{CD}^{+}$and $\mathrm{V} \beta 17^{+} \mathrm{CD}^{+} \mathrm{T}$ cells from patient \# 2 suggests that there were clone specific $T$ cell expansions not $\mathrm{V} \beta$ family specific expansions. The presence of discrepant TCR repertoire in RA synovial fluid provided good supportive evidence that some type of antigen selection process occurs. Our studies have shown that the oligoclonality was not equally distributed between $\mathrm{CD}^{+}$and $\mathrm{CD}^{+} \mathrm{T}$ cells. 
The finding that the oligoclonal expansions are primarily confined to $\mathrm{CD} 8^{+} \mathrm{T}$ cells suggests that cytotoxic $T$ cells or regulatory suppressor $T$ cells were activated. The clonal expansions were found in 5 out of from 10 normal adults and the clones responsible for such dominant bands were identified as $\mathrm{CD}_{45 \mathrm{RO}}$, which is the marker for the activated or memory $T$ cells (Hingorani et al. 1992). However, studies of the SFMCs from patients with other inflammatory arthritis will be needed to determine whether the $\mathrm{V} \beta$ discrepancies that we observed are specific for rheumatoid arthritis.

We found 2 concordant patterns of clonal expansions from the SFMCs and the PBMCs; one in $\mathrm{CD}^{+} \mathrm{V} \beta 5^{+} \mathrm{T}$ cells from patients $\# 1$, which are composed of CDR3s with 9 amino acids and one in $\mathrm{CD}^{+} \mathrm{V} \beta 18^{+} \mathrm{T}$ cells from patients $\# 2$, which are composed of CDR3s with 10 amino acids. The synovial $T$ cell clones might be derived from the dominant pool of the peripheral blood $T$ cells. But gene sequencing of these clones must be performed to determine that these clones in the SFMCs and the PBMCs from the same patient are exactly identical.

In conclusion, we found that there were definite $T$ cell activations in synovial site and clonal expansions of $T$ cells in both the SFMCs and the PBMCs from RA patients. The clonal patterns of $T$ cells were discrepant between the PBMCs and the SFMCs even in the same patient. These findings suggest that the pathogenic $T$ cells might expand in the inflamed synovial site or migrate to the inflamed synovial site. But our study could not demonstrate a common pattern of clonal expansions in the SFMCs from 3 RA patients tested. The findings indicate, however, that $T$ cell subpopulations expressing different TCR variable genes were involved in the pathogenesis in different RA patients. Therefore, different TCR variable gene could be used to gain further knowledge in the identification of relevant antigens and pathogenic $T$ cells.

\section{REFERENCES}

Bucht A, Oksenberg JR, Lindblad S, Gronberg A,
Steinman L, Klareskoo L : Characterization of $T$ cell receptor $\alpha \beta$ repertoire in synovial tissue from different temporal phases of rheumatoid arthritis. Scan J Immunol 35: 159-165, 1992

Candeias S, Waltzinger C, Benoist C: The V $\beta 17^{+} \mathrm{T}$ cell repertoire: skewed $\mathrm{J} \beta$ usage after thymic selection : dissimilar CDR3s in $\mathrm{CD}^{+}$versus $\mathrm{CD}^{+}$cells. $J$ Exp Med 174: 989-1000, 1991

Chatila MK, Pandolfi F, Stamenkovich I, Kurnik JT: Clonal dominance among synovial tissue infiltrating lymphocytes in arthritis. Hum Immunol 28: 252-257, 1990

Chomczynski P, Sacchi N: Single step method of RNA isolation by acid guanidium thiocyanatephenol-chloroform extraction. Anal Biochem 162: 156-159, 1987

Choi Y, Herman A, DiGuisto D, Wade T, Marrack $P$, Kappler J: Residues of the variable region of the $\mathrm{T}$ cell receptor $\beta$ chain that interact with $S$. aureus toxin superantigens. Nature 346 : 471-473, 1991

Cooper SM, Roessner KD, Naito-Hoopes M, Howard DB, Guar LK, Budd RC: Increased usage of $\mathrm{V} \beta 2$ and $\mathrm{V} \beta 6$ in rheumatoid synovial fluid T cells. Arthritis Rheum 37: 1627-1636, 1994

Cush JJ, Lipsky PE: Phenotypic analysis of synovial tissue and peripheral blood lymphocytes isolated from patients with rheumatoid arthritis. Arthritis Rheum 31: 1230-1238, 1988

Harris ED: Rheumatoid arthritis: pathology and implication for therapy. $N$ Engl $J$ Med 322: 1277-1289, 1990

Heeg $\mathrm{K}$, Bendigs S, Meithke T, Wagner $\mathrm{H}$ : Induction of unresponsiveness to the superantigen staphylococcal enterotoxin B: cyclosporin A resistance split unresponsiveness unfolds in vivo without preceding clonal expansion. Int Immunol 5: 929-937, 1993

Hingorani R, Choi IH, Akolkar P, Gulwani-Akolkar B, Pergolizzi R, Silver J, Gregersen PK : Clonal dominance of $\mathrm{T}$ cell receptors within the $\mathrm{CD}^{+} \mathrm{CD}^{+} 5 \mathrm{RO}^{+}$subset in normal human subjects. J Immund 151: 5762-5769, 1993

Howel MD, Diveley JP, Lundeen KA, Esty A, Winters ST, Carlo DJ, Brostoff SW: Limited T cell receptor $\beta$ chain heterogeneity among interleukin-2 receptor positive synovial $\mathrm{T}$ cell suggests a role for superantigen in rheumatoid arthritis. Proc Natl Acad Sci USA 88: 1092110925, 1991

Miethke T, Wahl C, Heeg K, Wagner H: Acquired resistance to superantigen-induced $\mathrm{T}$ cell shock. J Immund 150: 3776-3784, 1993 
Miethke T, Wahl C, Gaus H, Heeg K, Wagner H: Exogenous superantigens acutely trigger distinct levels of peripheral $\mathrm{T}$ cell tolerance/ immunosuppression: dose-response relationship. Eur J Immund 24: 1893-1902, 1994

Nepom GT, Byers P, Seyfried C, Healey LA, Wilske KR, Stage D, Nepom BS: HLA genes associated with rheumatoid arthritis : identification of susceptibility alleles using specific oligonucleotides probes. Arthrits Rheum 32: 1521, 1989

Paliard F, Sterkers G, Vaquero C: Transcriptional and post-transcriptional regulation of $T C R$, CD4 and CD8 gene expression during activation of normal human $T$ lymphocytes. EMBO J 9: 1867-1872, 1990

Paliard X, West SG, Lafferty JA, Clement JR, Kappler JW, Marrack P, Kotzin BL: Evidence for the effects of a superantigen in rheumatoid arthritis. Science 253: 325-329, 1991

Posnett DN, Gottlieb A, Bussel JB, Friedman SM, Chiorazzi N, Li Y, Szabo P, Farid NR, Robinson MA: $T$ cell antigen receptors in autoimmunity. J Immunol 141: 1963-1969, 1988

Scottini A, Imberti L, Gorla R, Cattabeo R, Primi $D$ : Restricted expression of $T$ cell receptor $V \beta$ but not $\mathrm{V} \alpha$ genes in rheumatoid arthritis. Eur
J Immunal 21: 461-466, 1992

Shirosky JB, Tocum DE, Wilder RL, Klippel JH: Experimental basis of innovative therapies of rheumatoid arthritis. Concepts Immunopathol 7: 106-144, 1989

Singer PA, Balderas RS, Theofilopolus AN: Thymic selection defines multiple $T$ cell receptor $V$ beta repertoire phenotype at the CD4/CD8 subset level. EMBO J 9: 3641-3648, 1990

Stastny P: Association of the $\mathrm{B}$ cell alloantigen DRw4 with rheumatoid arthritis. $N$ Engl $J$ Med 298: 869-871, 1978

Urban JL, Kumar V, Kono DH, Gomez C, Horvath SJ, Clayton J, Ando DG, Sercarz EE, Hood L : Restricted use of $T$ cell receptor $V$ genes in murine autoimmune encephalomyelitis raises possibilities for antibody therapy. Cell 54: 577 592, 1988

Van Boxel JA, Paget SA: Predominantly $T$ cell infiltrate in rheumatoid synovial membrane. $N$ Engl J Med 293: 517-520, 1975

Zaller DM, Osman G, Kanagawa O, Hood L: Prevention and treatment of murine experimental allergic encephalomyelitis with $T$ cell receptor $\mathrm{V} \beta$-specific antibodies. $J$ Exp Med 171: 19431955,1988 